\title{
Hydrogeological and hydrochemical features of an area polluted by heavy metals in central Nicaragua
}

\author{
J. A. Mendoza · T. Dahlin • G. Barmen
}

Publisher's Note:

Hydrogeology Journal (2006), pp 777-784

DOI 10.1007/s10040-005-0462-5

The figures in this article were inadvertently printed in black and white instead of in colour. We apologize very much for this error and provide you here with the corrected printed version.

\begin{abstract}
Geophysical and hydrochemical surveys were used to investigate the hydrogeological conditions in one of the Río Sucio microbasins, in central Nicaragua. Zones of vertical structures (i.e. fractures and quartz veins) and weathering were mapped using Continuous Vertical Electrical Soundings (CVES), as such zones are of major importance for groundwater transport. Water from the springs was analysed to determine concentrations of major ions and heavy metals. Low ion concentrations and ${ }^{18} \mathrm{O}$ analyses indicate that the springs occur close to their recharge areas and there is a relatively rapid groundwater circulation. Mercury $(\mathrm{Hg}$ ) content in the springs was low, while comparatively high amounts of lead $(\mathrm{Pb})$ were found. The results presented here demonstrate the important function of weathering and tectonics in the occurrence of groundwater systems in the basin. $\mathrm{Hg}$ and $\mathrm{Pb}$ found in the springs' water reveal the existence of an increase in pollution sources
\end{abstract}

Received: 8 March 2005 / Accepted: 25 April 2005

Published online: 30 August 2006

(C) Springer-Verlag 2006

The online version of the original article can be found at http://dx.doi.org/10.1007/s10040-005-0462-5

\section{J. A. Mendoza $(\bowtie)$}

Centro de Investigaciones Geocientíficas, Universidad Nacional

Autónoma de Nicaragua (CIGEO, UNAN-Managua),

Col. Miguel Bonilla \#165, Apartado Postal, A-131, Managua,

Nicaragua

e-mail: alfredo.mendoza@tg.lth.se

Tel.: +(505)-277-0621

Fax: +(505)-277-0613

T. Dahlin · G. Barmen

Department of Engineering Geology, Lund University,

Box 118, S-221 00 Lund, Sweden disseminating in the area. More than 100 years of using mercury in the gold-mining industry and releasing wastes into rivers has affected water quality and ecosystems. Further investigations are needed in this area to determine the groundwater vulnerability to this pollution as this resource may be needed in the future.

Résumé L'article présente les résultats des prospections géophysiques et géochimiques qui ont investigué les conditions hydrogéologiques dans un des micro bassins de Rio Suci, situé dans la part centrale de Nicaragua. Par la méthode du sondage électrique vertical (SEV) on a cartographié des structures verticales, comme des fractures et des veines de quartz, ainsi que des zones de désagrégation. On a analysé les eaux des sources afin de déterminer la teneur en ions majeurs et en métaux lourdes. Les faibles teneurs en ${ }^{18} \mathrm{O}$ montrent que les sources sont toutes prés de leurs aires de recharge et qu'il s'agit d'une circulation rapide de l'eau. La concentration en mercure est faible par rapport á la concentration en plomb. Les résultats montrent l'importance de la tectonique et des zones de désagrégation dans l'écoulement des eaux souterraines. La présence du mercure et du plomb montre l'existence d'une source de pollution dans la zone. Plus de cent ans d'industrie mineure qui a déchargé les déchets résiduelles dans les rivières ont beaucoup affecté la qualité des eaux et des écosystèmes en général. Des investigations supplémentaires sont nécessaires pour déterminer la vulnérabilité des eaux aux ces polluants dans les conditions d'utilisation de cette ressource dans un proche avenir.

Resumen Este trabajo presenta resultados de estudios geofísicos e hidroquímicos utilizados para investigar las condiciones hidrogeológicas en una de las microcuencas del Río Sucio, en Nicaragua central. Zonas de estructura vertical (i.e. fracturas y vetas de cuarzo) y meteorización fueron delimitadas usando Sondeos Eléctricos Verticales Continuos (SEVC), dado que tales zonas son de importancia mayor para el transporte de agua subterránea. Agua de manantiales fue analizada para determinar concentraciones iónicas y de metales pesados. Las bajas concentraciones iónicas y análisis de ${ }^{18} \mathrm{O}$ indican que los manantiales se forman próximo a sus áreas de recarga y que hay una circulación relativamente rápida de agua subterránea. El contenido de mercurio $(\mathrm{Hg})$ en los manantiales fue relativamente bajo mientras se encontraron comparativamente 
altas cantidades de plomo $(\mathrm{Pb})$. Los resultados presentados aquí muestran la importante función de la meteorización y tectónica en la ocurrencia de sistemas de agua subterránea en la cuenca. El $\mathrm{Hg}$ y $\mathrm{Pb}$ encontrados en agua de manantiales revela la existencia de un incremento en las fuentes de contaminación que se diseminan en el área. Más de 100 años de uso de mercurio en la industria minera y liberación de los desechos en los ríos ha afectado la calidad del agua y los ecosistemas. Se necesitan más investigaciones en el área para determinar la vulnerabilidad del agua subterránea a esta contaminación, dado que este recurso puede necesitarse en el futuro.

Keywords Hydrochemistry - Geophysical methods · Stable isotopes $\cdot$ Contamination $\cdot$ Nicaragua

\section{Introduction}

In areas where surface waters have been polluted as a result of industrial activity, groundwater has become a main concern, as it constitutes the alternative water supply. However, surface waters may infiltrate and reach aquifers, consequently carrying hazardous substances to the groundwater as well. An important cause of groundwater pollution is associated with mining activities, since toxic substances (i.e. heavy metals), which are typically used throughout the exploitation process, are often released into the environment. For example, artisanal small-scale mining is one of the main sources of mercury $(\mathrm{Hg})$ emissions to the environment worldwide, and particularly in North, Central and South America (Nriagu 1996; Pirrone et al. 1998; Lacerda 2003). Often the high toxicity of such heavy metals leads to the definitive loss of the water resource. The concern about how water pollution affects the environment has triggered several investigations (Barker 1996; Kayabali et al. 1998; Abdul Nassir et al. 2000). As the character of the pollution is complex and the pollution sources may be spread over large areas, these studies combine chemical, geological and geophysical methods, and often include the identification of the groundwater occurrence in order to determine the extent of contamination. However, few studies have been carried out in Latin America, where mining has in fact been extensive in populated areas.

In the central region of Nicaragua, gold-mining activities have led to continuous contamination of water basins since the 19th century (Feust 1912). One of those water basins is Río Sucio (formerly named Río Artiguas), where a dispersed cluster of small-scale mills still use mercury $(\mathrm{Hg})$ and cyanide $(\mathrm{NaCN})$ to process ore. The process wastes are then directly released into the water. In addition, the amalgams are frequently burnt by the rivers or in backyards, making it difficult to identify the sources of pollution. Consequently, most of the mercury used to refine gold is released into the environment and there is no possibility to assess responsibility for this pollution (Mendoza 2002).

Earlier analyses of water quality in the Río Sucio watershed indicated that the mercury levels are above the min- imum recommended for drinkable water (Romero 1996). Mercury and lead $(\mathrm{Pb})$ have been found in soils, sediments and waters of the basin (André et al. 1997). Further, a study of mercury in miners' hair indicates the need for a continuous monitoring of the effect of water quality on the population living in the area (Silva 1994), since the pollution sources are active, seasonal and mobile, and the population is likely to use surface water for domestic purposes. Unfortunately, there are no previous hydrogeological investigations reported on the Río Sucio area. Geological studies made in the area give a tectonic and lithologic description, but are mainly aimed at assisting ore prospecting, emphasising the gold bearing quartz veins locations in the area (Hodgson 1972; Darce 1990; Carranza 1991). Therefore, increasing knowledge of groundwater systems is needed in the area as a way to assess their vulnerability to pollutants.

This study aims to examine geophysical and hydrochemical information about the Río Sucio watershed, with a focus on the hydrogeological conditions in the study area. This paper includes a geological reconnaissance, a geophysical survey and hydrochemical analyses of springs. A representative group of springs was sampled for chemical analyses, while the geophysical surveys were carried out crossing five springs. Geophysical results for two springs are presented here. The electrical resistivity method was used to map geological materials related to groundwater systems.

\section{Area Description}

The study area is located in central Nicaragua. Figure 1 shows the study area, which is one of the Río Sucio microbasins, covering an area of $28 \mathrm{~km}^{2}$. The main pollution source is located in the upper part of the microbasin; it is the miners' village of Santo Domingo. The climate is humid tropical mountainous, with annual average temperatures of $23-24^{\circ} \mathrm{C}$. Heavy rains characterise the region, making it difficult to set a limit between dry and wet seasons. The steep topography becomes less sharp from north to south.

The young drainage system has developed under a structural control where faults, fractures and joints lead to a rectangular sort of flow pattern regarding surface waters. Streams in the basin sum up a total length of $30 \mathrm{~km}$, which is relatively long considering the basin area. Flow measurements in a centrally located cross-section of the main river indicate an approximate discharge of $1.6-8.5 \times 10^{4} \mathrm{~m}^{3} /$ day.

Figure 2 shows the two main geological units present in the basin; the old pyroclastic rocks of the Matagalpa group in the south and the basalt to andesite lava flows of the Coyol group in the central and northern part. Several plugs of acid composition have intruded these units (Hodgson 1972; Ehrenborg 1996).

The upstream part of the area is cut by several faults/fractures in an east-west direction. Hydrothermal solutions filled these fractures and formed the gold bearing quartz veins. A second generation of tectonic movements in the south-north direction caused the quartz veins to become segmented and displaced a few meters (Darce 1987). 


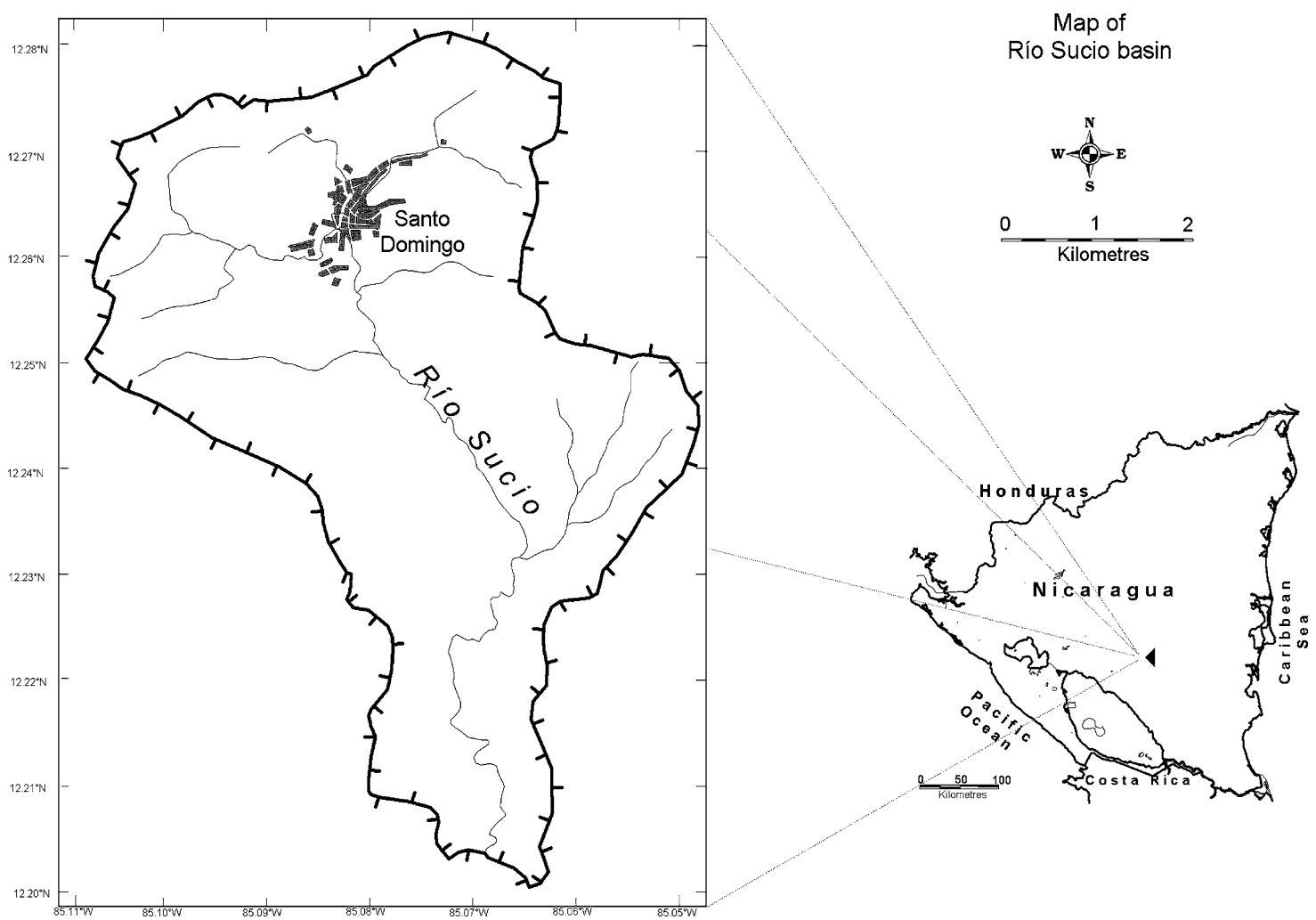

Fig. 1 The study area at Río Sucio basin in the central mountainous region of Nicaragua

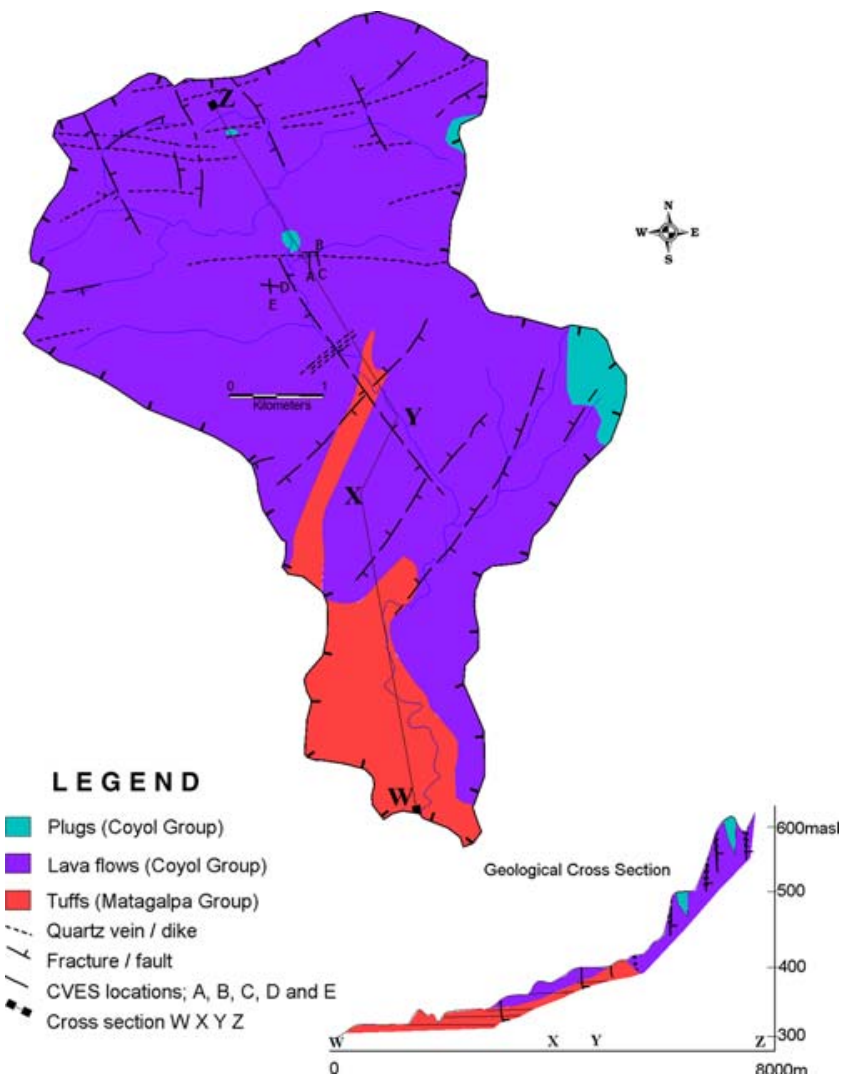

Fig. 2 The lithological and tectonic features of the area and location of CVES surveys (A-E)

\section{Methodology}

A geological reconnaissance was carried out in the region in order to (a) identify areas with different lithologies (b) get a general, regional grasp of the principal tectonic structures and (c) develop a sense of the orientation of minor faults and fractures. The reconnaissance was carried out together with analysis of aerial photographs to locate major structures like faults, fractures, dikes and quartz veins.

Continuous Vertical Electrical Sounding (CVES), which combines lateral with vertical data acquisition, was the applied resistivity imaging technique. The multi-electrode ABEM Lund Imaging System (Dahlin 1996) was used in varied layouts at diverse locations in the area to locate fractures, zones of quartz veins and to map weathered layers. Examples of five CVES, two using the Wenner array, one using Wenner-Schlumberger array and two using the dipole-dipole array are presented in this work. Documentation of the ground lithology and observations in available mine shafts was done along each line. Three of the CVES lines had a length of $160 \mathrm{~m}$, with a 2-m electrode spacing, and two lines had a length of $200 \mathrm{~m}$, with 2-m electrode spacing. The CVES were performed at several sites and results from two sites with geological setting representative of the area are presented here, crossing springs with weathered rock zones and a quartz vein area (Fig. 2).

After data collection, processing was performed using the Res2dinv algorithm, which generates a two-dimensional (2D) model of the subsurface resistivity distribution (Loke 
1999). This $2 \mathrm{D}$ resistivity model was obtained by applying the robust $\left(\mathrm{L}_{1}\right.$-norm) inversion method to the measured data (Loke et al. 2003). Due to the steep topography the inversion had to be based on the generation of a distorted finite element grid of the subsurface. The resistivity model fitness was evaluated by the mean residuals value, which is a comparison between the resistivity values calculated on the model and the measured apparent resistivity. In addition to the multi electrode resistivity survey, punctual resistivity measurements were made using an electrode separation of $0.1 \mathrm{~m}$ in different kinds of exposed materials. In this way, reference resistivity for different kinds of materials was compared with the results of the multi electrode surveys.

An inventory of springs in the area was performed which included location with GPS and documentation of each spring site, integrating land use, soil type, geology, seepage site and amount of discharge, when possible. Further, 20 typical springs were sampled for hydrochemical analysis, selected according to the seepage type, geographic location and accessibility. Analysis of ${ }^{18} \mathrm{O}$ was also performed in order to identify recharge areas since the content of this isotope may vary as a function of the average altitude of recharge. The water samples included one from rainwater and two from the polluted main stream of Río Sucio. Analyses of $\mathrm{NO}_{3}{ }^{-}, \mathrm{SO}_{4}{ }^{2-}$, $\mathrm{S}_{2}{ }^{-}, \mathrm{Cl}^{-}$, and $\mathrm{Fe}^{2+}$ were done with a field spectrophotometer Hach $\mathrm{DR} / 2010 \mathrm{~Pb}$ and $\mathrm{Hg}$ were analysed by a SpectrAA-20 VARIAN atomic absorption spectrophotometer. The laboratory analyses were performed in two laboratories, the National University of Nicaragua (UNANManagua) and the Department of Geophysics, University of Copenhagen.

\section{Results}

The results of the combined geophysical surveys and geological reconnaissance show that tectonics and weathering processes have dominant influence on the occurrence of groundwater flow systems. Figure 3 shows the 2D resistivity inversion results for five CVES lines performed in the upper part of the basin. Lines A and B were located at a site where the geology is characterized by a $5-10 \mathrm{~m}$ thick quartz vein intruding weathered andesite-basalt flows (see Fig. 2). Both resistivity lines meet at a spring location and the south-north line (Line A) crosses a stream three times. These two resistivity lines show three layers with different resistivity values. On the top, there is a $1-5 \mathrm{~m}$ thick layer with values of $60-220 \mathrm{ohm}-\mathrm{m}$. Below this layer, the resistivity drops to $17-46 \mathrm{ohm}-\mathrm{m}$, becoming at least $10 \mathrm{~m}$ thick. This area reaches the surface at the spring location at Line B (see Fig. 3). Two vertical patterns, corresponding to quartz vein areas are located at 95 and $120 \mathrm{~m}$ on Line A, giving very high resistivity values ( $>220 \mathrm{ohm}-\mathrm{m}$ ). The strong correlation between tectonics and groundwater occurrence is confirmed on Line $\mathrm{C}$, where a spring is found directly on top of a quartz vein. Lines $\mathrm{E}$ and
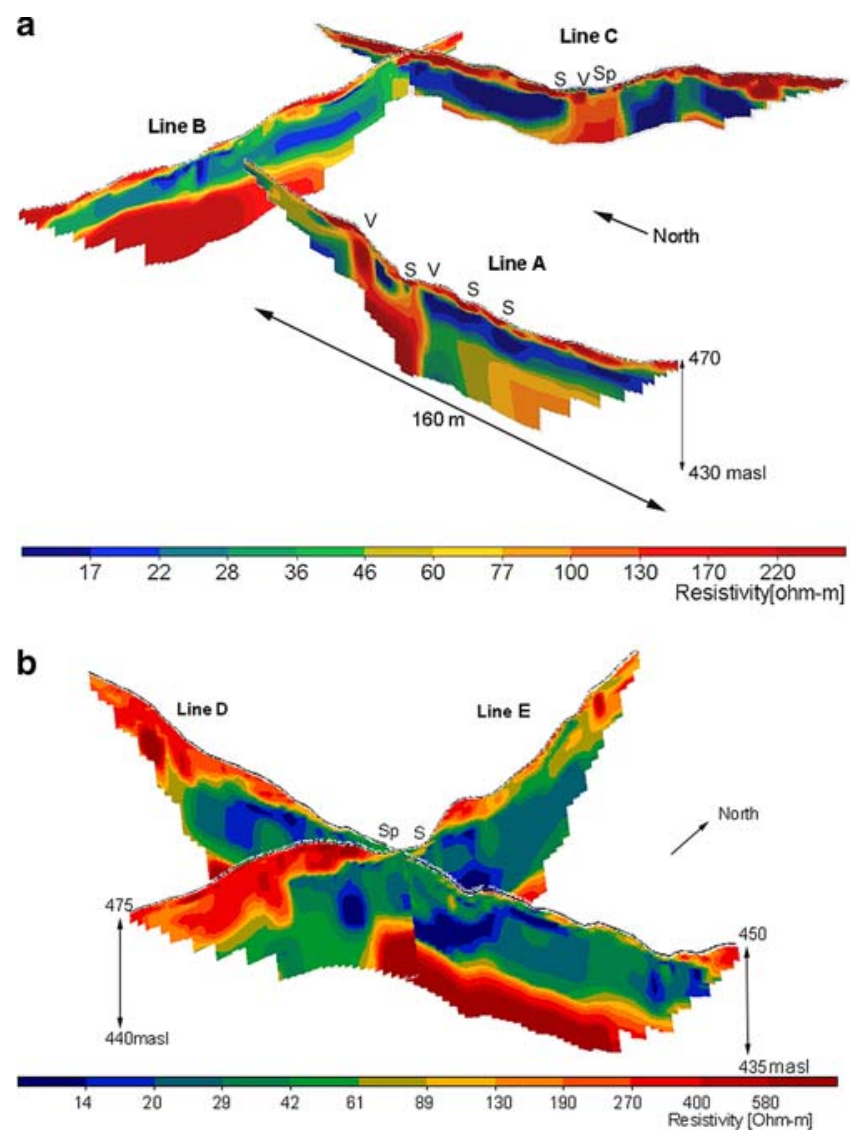

Fig. 3 CVES results. a), the resistivity inversion models for Line A, Line B and Line C, all $160 \mathrm{~m}$ long. Line A shows coarse-grain material on top of a low resistive layer with clay weathered material. Quartz veins $(V)$ stand out as high resistive vertical zones. A spring $(S p)$ is found on top of a quartz vein $(V)$ on Line C. b), Lines E and D show the low resistive clay weathered zones reaching the surface at spring 61 along a stream valley (each line is $200 \mathrm{~m}$ long). Sp Spring, $S$ Stream, $V$ Quartz vein

D were located so that they crossed one of the analysed springs (\#61). Both lines show an upper layer with high resistivity values (>130 ohm-m) in the hilltops and hillsides, which get thinner towards the valley areas. Along Line $\mathrm{D}$ at the stream valley the resistivity values are lower $(<42$ ohm-m).

The resistivity responses of different materials were estimated using punctual resistivity measurements. Figure 4 shows that the highest resistivity values were observed in massive quartz, followed by unsaturated weathered volcanic rock. Lower values were found in water-saturated weathered rock and surface water.

The inventory of the area reveals 95 springs of three types: wetland springs, punctual springs and shallow wells (probably punctual springs that have been converted to shallow wells by digging). Wetland springs can cover areas of up to $5,000 \mathrm{~m}^{2}$. Punctual springs and wells occur in areas of steeper topography and may be associated with local tectonics. The altitude of the springs varies from $331 \mathrm{~m}$ a.s.l. for those in the south and centre of the region to $731 \mathrm{~m}$ a.s.l. at the northern borders of the basin. $\mathrm{pH}$ values ranges from 5.81 to 7.47 , while conductivity varies from 170 to 


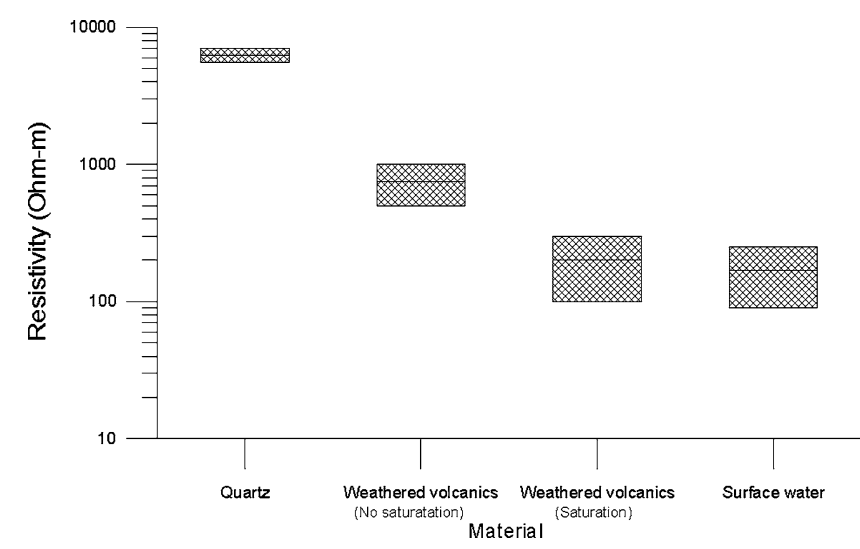

Fig. 4 Ranges of resistivity responses from different materials in the area

$46 \mu \mathrm{S} / \mathrm{cm}$. (Aronsson and Wallner 2002) The spring locations are presented in Fig. 5.

The analyses of groundwater from 20 springs generally show low ion concentration values (Fig. 5). Relatively high values of $\mathrm{NO}_{3}{ }^{-}, \mathrm{SO}_{4}{ }^{2-}$, and $\mathrm{Cl}^{-}$were found in the springs close to the village. Analyses of samples from springs 23, 25 and 51 were excluded from the diagrams of Figs. 5 and 6 since the ion balance error was higher than the accepted error for this study (11\%). Figure 6 presents a Piper diagram indicating that regarding the hydrochemical facies, the spring waters can be classified as calcium type in the cations-triangle, and as bicarbonate type in the anions-triangle. Plots in the central diamond suggest that the spring waters are affected by alkaline lithology. Detectable mercury concentrations were found in locations $39(0.0003 \mathrm{mg} / \mathrm{l})$ and $89(0.0006 \mathrm{mg} / \mathrm{l})$, but none of them exceed the health limit of $0.001 \mathrm{mg} / \mathrm{l}$ (WHO 1996). Water samples B and C, taken in the main river stream close to the major pollution sources, present higher mercury contents than the water samples from the springs. The highest lead concentrations were found in springs $23(0.011 \mathrm{mg} / \mathrm{l})$ and $51(0.013 \mathrm{mg} / \mathrm{l})$. Other high values of $\mathrm{Pb}$ were found in springs $8,28,39,49,89$ and 114 , all located close to the basin borders.

The ${ }^{18} \mathrm{O}$ analyses indicate that the springs occur at an altitude that ranges from 0 to $150 \mathrm{~m}$ from the average elevation of their recharge areas. The results of ${ }^{18} \mathrm{O}$ are presented in Fig. 7 as function of the altitude of the springs together with an estimation of the average altitude of the recharge areas.
Fig. 5 Hydrochemical characteristics of groundwater from springs in the Río Sucio basin. The table presents heavy metals $(\mathrm{Hg}, \mathrm{Pb})$ content in the sampled springs $(\mathrm{mg} / \mathrm{l})(<\mathrm{id}=$ value lower than detection limit)

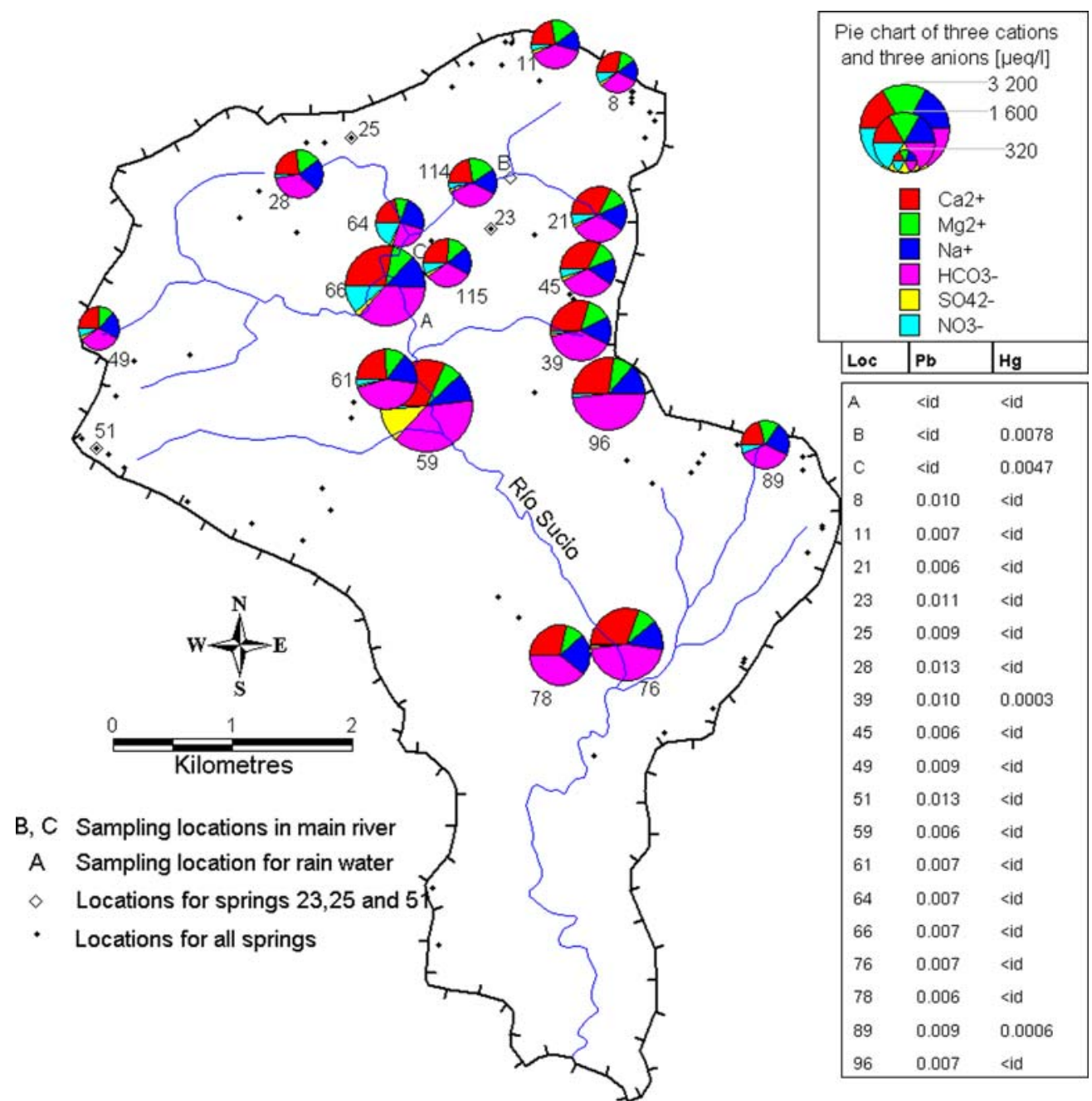


Fig. 6 Piper diagram. Spring waters at Río Sucio Basin

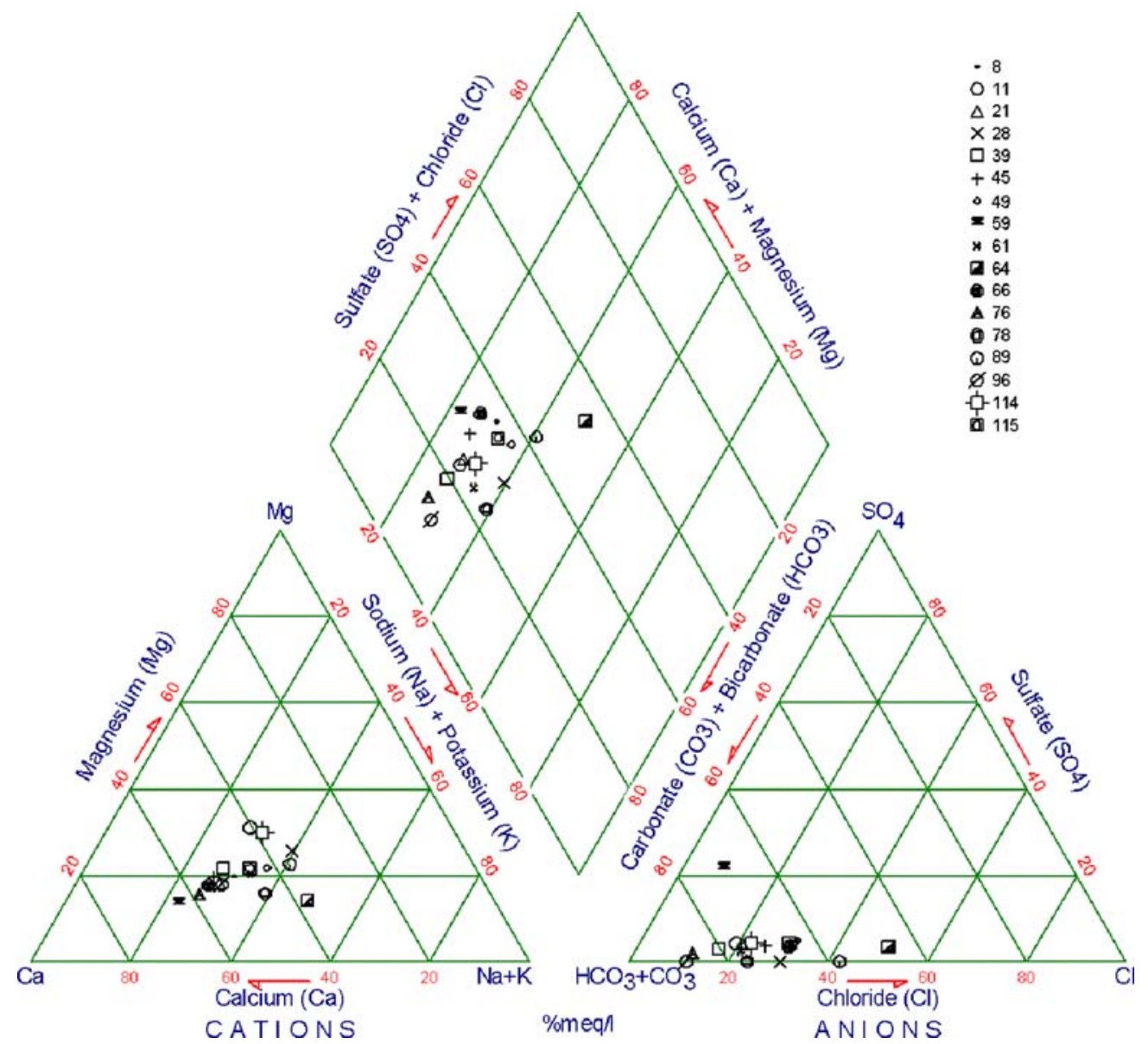

ANIONS

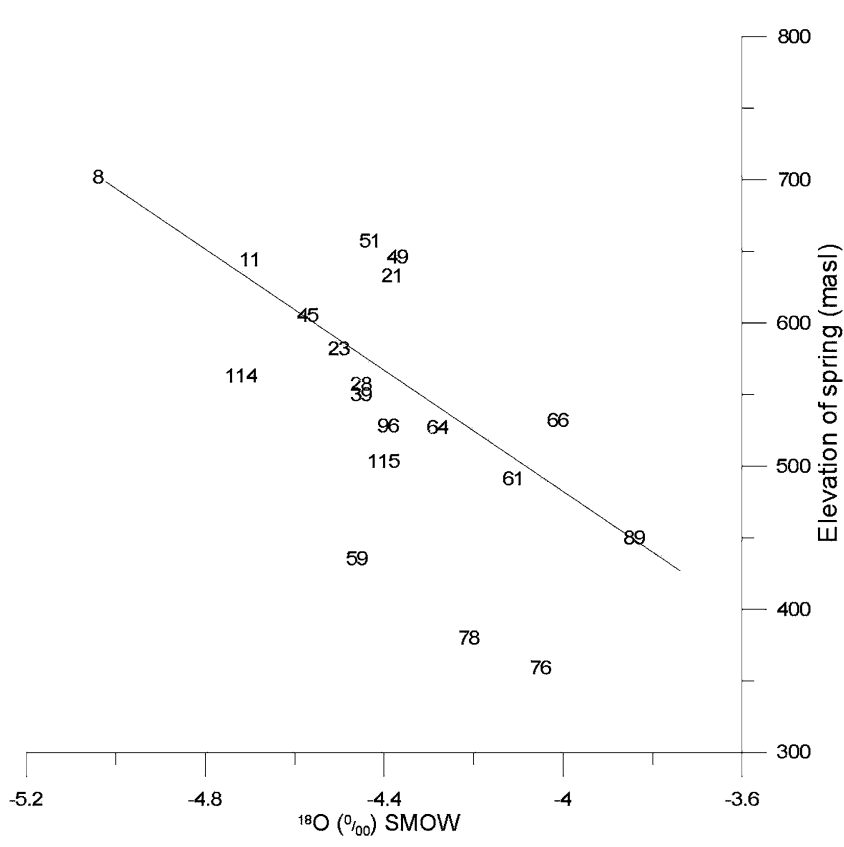

Fig. $7{ }^{18} \mathrm{O}$ results plotted against the elevation of the springs. The trend line is adjusted to the elevations of spring 8 and 89 , since those springs are judged to be located very close to their recharge area

\section{Discussion}

Using CVES, it was possible to clearly delineate three distinctly different resistivity layers at the investigated locations. For all lines, the results show relatively high resistivity values in the top layer, which is associated with hydraulically permeable coarse-grained material. This might be caused by material transported due to natural processes or leached weathered soil, but it might also originate from material removed from mining activities on the surface. The latter is the case for Lines A and B, where mining has been reported around the quartz vein. A second, underlying, layer is then found which appears to be clay weathered material. This clay layer may have low hydraulic conductivity, which explains the fact that a spring is formed where this layer meets the surface on Line E. The bottom resistivity layer is interpreted as less weathered or fresh rock, since very high values were obtained. An intrusive body was visible at the west extreme of Line B (see Fig. 3). As Line $\mathrm{E}$ reaches the hillsides and approaches spring 61 and the stream, the low resistive clay layer gets near the surface. This could have implications for discharge, since water infiltrating the uppermost coarse-grained layer can be discharged along the streams. This can also be appreciated on Line $\mathrm{D}$, where the top layer is mostly the low resistive. 
As the resistive quartz vein appears to have high secondary porosity, it contributes to the spring occurrence on Line C.

The low ion concentrations in the analysed spring water can probably be explained by infiltrating water that travels very quickly from recharge to discharge areas and consequently, is not in contact with minerals in the rock for enough time for chemical reaction to take place. Relatively higher ion concentrations were observed in spring waters closer to the main river, accordingly the groundwater appears to be in longer contact with weathered materials.

The ${ }^{18} \mathrm{O}$ analyses indicated that $55 \%$ of the sampled springs are located very close to their recharge areas, with less than $30 \mathrm{~m}$ of difference in altitude, which together with the low ions concentrations, elucidate the relatively rapid groundwater circulation.

Conversely, springs located in the southern part of the basin at lower altitudes seem to be less close to their recharge areas, presumably due to higher hydraulic conductivities in the pyroclastic rocks present in the area. There, the basalt to andesite lava flows of Coyol become thinner southwards, and the very weathered and porous pyroclastic rocks of the Matagalpa unit often appear as 'windows' (Darce 1987; Ehrenborg 1996). Figure 2 shows a cross section along the river course where a change in lithology can be observed. The high porosity of tuffs is associated with high hydraulic conductivity, permitting water to be transported longer distances before forming springs. Nevertheless, considering the basin area the amount of springs occurring in the Río Sucio basin is high, indicating that most of the groundwater is discharged into the springs, rather than forming large regional aquifers.

The main mercury source was shown to be in the village and its surroundings, where a small-scale semiindustrial plant and several hand-made mills are used for gold processing. Other diffuse sources are spread in the basin, as individual miners looking for new mineral prospects are sometimes processing gold in situ. The latter may explain the mercury found at two of the springs (39 and 89).

\section{Conclusions}

Vertical structures as faults and quartz veins act as conducts to transport water in the upstream part of the Río Sucio basin. The results of geological reconnaissance and resistivity imaging demonstrate the important function of tectonics and weathering in the groundwater systems. However, more field studies are needed to establish a reliable picture of groundwater flow pattern and groundwater and surface water interaction. Such studies are in progress.

The water chemistry analyses at the selected springs show low ion concentrations, indicating that the groundwater circulation through the basin is rapid. The water chemistry is characteristic of lava flow environments. The ${ }^{18} \mathrm{O}$ analyses indicate that the springs occur very close to the average elevation of their recharge areas, in particular in the upper part of the basin.

As the lithology changes southwards to a more weathered pyroclastic rock, the occurrence of the springs tends to take place at longer distances from their recharge areas. In the downstream part of the basin tectonic features may have less importance for groundwater flow transport, as the porous pyroclastic deposits may take this function instead.

The mercury $(\mathrm{Hg})$ content in the analysed springs was low, while the lead $(\mathrm{Pb})$ amounts found were relatively high. Since no anthropogenic source of pollution has been reported, lead might be of natural origin.

Acknowledgments This work was conducted as part of a multidisciplinary research program funded by the Swedish International Development Agency (Sida/SAREC). Technical and logistical support was provided by the Department of Engineering Geology at Lund University (Sweden) and Centro de Investigaciones Geocientíficas at UNAN-Managua, respectively. Prof. Leif Bjelm offered valuable guidance and comments. M. Aronsson and C. Wallner devoted time and effort to collect field data for water analyses. Family Duarte is specially acknowledged as their assistance made fieldwork less difficult under the tropical conditions at Río Sucio.

\section{References}

Abdul Nassir SS, Loke MH, Lee CY, Nawawi MNM (2000) Saltwater intrusion mapping by geoelectrical imaging surveys. Geophys Prosp 47:647-661

André L, Rosén K, Torstendahl J (1997) Minor field study of mercury and lead pollution from gold refining in central Nicaragua. MSc Thesis, ISBN 1402-1617, Luleå University of Technology, Sweden, $154 \mathrm{pp}$

Aronsson M, Wallner C (2002) Inventory of springs and hydrochemical investigations of groundwater in the drainage basin of Sucio River, Nicaragua. MSc Thesis, Lund University, Sweden, 105 $\mathrm{pp}$

Barker RD (1996) The application of electrical tomography in groundwater contamination studies. 58th EAGE conference, Amsterdam, The Netherlands, Extended Abstracts, $82 \mathrm{p}$

Carranza G (1991) Lithostratigraphy, tectonics and geochemistry of the Buena Vista-La Libertad area. Lic Thesis no 1991:07L, Luleå University, Sweden, $99 \mathrm{pp}$

Dahlin T (1996) 2D resistivity surveying for environmental and engineering applications. First Break 14:275-283

Darce M (1987) Geology of La Libertad mining district and its surroundings, Nicaragua. SGAB/INMINE/SAREC Report URAP $87002,12 \mathrm{pp}$

Darce M (1990) Mineralogic alteration patterns in volcanic rocks of the La Libertad gold mining district and its surroundings, Nicaragua. Eco Geol 85:1059-1071

Ehrenborg (1996) A new stratigraphy for the Tertiary volcanic rocks of Nicaraguan Highlands. Geol Soc Am Bull 108:830-842

Feust A (1912) Gold mines of Chontales, Nicaragua. Mining and Scientific Press, Dewey and Co., San Francisco, USA, 12 pp

Hodgson G (1972) Mapa Geológico de la hoja topográfica La Libertad. [Geological map of La Libertad sheet] Catastro e Inventario de Recursos Naturales. Managua, Nicaragua [in Spanish]

Kayabali K, Yüksel F, Yeken T (1998) Integrated use of hydrochemistry and resistivity in groundwater contamination caused by a recently closed solid waste site. Environ Geol 36:227234

Lacerda LD (2003) Updating global Hg emissions from small-scale gold mining and assessing its environmental impacts. Environ Geol 43:308-314 
Loke MH (1999) Rapid 2D resistivity inversion using the leastsquares method, Manual for RES2DINV, Geolectrical Imaging $2 \mathrm{D}$ and $3 \mathrm{D}, 43 \mathrm{pp}$

Loke MH, Acworth I, Dahlin T (2003) A comparison of smooth and blocky inversion methods in 2-D electrical imaging surveys. Explor Geophys 34:183-187

Mendoza JA (2002) Geophysical and hydrogeological investigations in the Río Sucio watershed, Nicaragua. Lic Thesis ISBN 91972406-0-X, Lund University, Sweden, 60 pp

Nriagu JO (1996) A history of global heavy metal pollution. Science 272:223-224

Pirrone N, Allegrini I, Keeler GJ, Nriagu JO, Rossman R, Robbins JA (1998) Historical atmospheric mercury emissions and depositions in North America compared to mercury accumulations in sedimentary records. Atmos Envir 32:929-940
Romero F (1996) Contaminación de $\mathrm{Hg}$ y $\mathrm{Pb}$ en fuentes de agua. area de Santo Domingo, Chontales $[\mathrm{Hg}$ and $\mathrm{Pb}$ contamination in water wells], Centro de Investigaciones Geo-científicas, Managua. [in Spanish], $21 \mathrm{pp}$

Silva G (1994) Diagnóstico da contaminação ambiental gerada pela actividade minerária sobre los ríos Súcio, Mico e Sinecapa, Nicaragua [Diagnose on the contamination caused by the mining activity in the rivers Sucio, Mico and Sinecapa]. Universidade Federal do Pará Centro de Geociências curso de postgraduação, Belem [in Portuguese]

World Health Organization (1996) Guidelines for drinking-water quality, 2nd edn. Vol. 2 Geneva, pp 940-949 